his failing eyesight compelled him to stop work at the Museum and he retired to his former home in Waynesville, North Carolina, where he died.

Dr. Gudger's bibliography was enormous: chiefly articles on odd facts about fishes, old natural history myths and the distribution and habits of the whale shark. He was primarily a library worker, with an extraordinary knowledge of ancient natural history literature. He conducted a vast correspondence on all sorts of topics, ranging from fishes to inaccuracies in magazine illustrations of steam engines. The arrival of his mail and his southern home-town paper brought him to the Museum early every morning before the main doors were open or the corridor lights on.

Dr. Gudger was an impressively tall, rosy-cheeked, silver-haired man with peering, bespectacled blue eyes. Due to his unusual appearance, his determined and emotional personality -as booming in enthusiasm as in anger- his departure from the Museum deprived us of one of our most colourful figures.

Dr. Gudger never married, $\mathrm{H}_{\Theta}$ is survived by $\mathrm{a}_{0}$ brother.

$$
\text { F. R. LAMontw }
$$

\section{Prof. J. R. H. Whiston, O.B.E.}

Prof. J. R. H. Whiston, head of the Applied Chemistry Branch in the Royal Military College of Science, died on February 28 after a short illness.

John Reginald Harvey Whiston was born at Gonalston on January 3, 1893, and attended Nottingham High School during 1902-11, when he obtained an open Exhibition in Natural Science at Jesus College, Oxford, where he obtained a first in chemistry in 1914. During the First World War he served (1914-16) as an officer in the sherwood Foresters, and from 1916 to the end in the R.F.C. as an experimental officer in the Seaplane Experimental Establishment at Martlesham Heath.

In 1919 Whiston returned to Oxford as a demonstrator in the Jesus College Laboratory, where he worked with the late D. L. Chapman on the hydrogen-chlorine reaction, particularly on the effect of oxygen, and with Sir Henry Tizard on indicator problems. After two further years in Oxford as a research chemist to the British Dyestuffs Corporation, he joined the staff of the Military College of Science at Woolwich in 1922.

The remainder of Prof. Whiston's career was spent in the Royal Military College of Science-he became an associate professor in 1936 and stayed with the College throughout its travels from Woolwich to Lydd, from Lydd to Stoke and from Stoke to its new permanent home in Shrivenham. At first his work was mainly on lubricants and on the improvement of petrols; but later he specialized more on Service explosives, and several government publications, including part of the new Services text-book of explosives, were written by him. In 1946 he was made O.B.E.

Prof. Whiston built up, in the College and outside, a reputation as an outstanding teacher and administrator, and he will be long remembered by the students, more than two thousand in number, who were taught by him. The staff of the College will always be grateful to him for his long labours on their behalf in official negotiations and for his neverfailing help and kindness to the junior members. $\mathrm{He}$ is survived by his widow, their married daughter, and by two grandchildren.

\section{Mr. John Pryce-Jones}

The unexpected death of John Pryce-Jones, so soon after his retirement because of ill-health, came as a profound shock to his many friends. He had been in indifferent health for some time, and early this year he had to undergo a major operation.

Pryce-Jones, who was sixty-two years of age, was born in Pencoider, and was educated at Llandyssul Grammar School and the University College of Wales, Aberystwyth. $\mathrm{He}$ belonged to an age which thought of university education as a great privilege, and throughout his life he maintained the academic interests of a true scholar while engaged in the chemical and administrative affairs of a prosperous industrial firm. After service in the R.N.V.R. as a meteorologist at Scapa Flow during the First World War, he joined the staff of Reckitt and Sons, Ltd., in 1919, and he remained with Reckitt and Colman, Itd., until his retirement last Septembor. During this time he became known as a leading expert on the manufacture and uses of ultramarine blue, and in 1950 he was appointed a director of Reckitt's (Colours), Ltd., when that company was formed.

Pryce-Jones was interested in all aspects of the chemistry of ultramarine, and among his fine collection were specimens of many shades. In particular, he was interested in its structure and in the influence of particle size, and he made important contributions to the improvement of the manufacture and application of this unusual material. His interest in lapis lazuli was such that he acquired a doop knowledge of its uses in medieval times, and he had a remarkable knowledge of art, in particular of the pigments used in paintings. He was an accepted authority, too, on oils and paints, and was keenly interosted in oil paintings and in methods used in the fakking of old masters.

During the nineteen-thirties, Pryce-Jones began to develop his interests in rheology, and his papers in the Journal of the Oil and Colour Chemists' Association on this subject were soon recognized as having more than a technical importance. They were, indeed, the beginning of a serios of studies in the field of rheology which he continued up to the time of his death, and they constituted a very considerable contribution to knowledge.

Pryce-Jones was especially interested in the various modifications of the phenomena associated with 'thixotropy', and he designed several instruments for their investigation. He was strongly of the opinion that there are two distinct modes of behaviour involved in reversible loss of consistency as a result of shearing, corresponding to lyophobic and lyophilic colloidal conditions, respoctively. He differentiated clearly between 'thixotropy' proper and 'false-body', though admitting that these can occur together in mixed systems. His nomenclature was sometimes unusual, but always lucid ; for example, he insisted that any measurable rigidity should indicate the use of the term 'gel', the term 'sol' being strictly reserved for liquids. He designed an ingenious 'double Couette' viscometer consisting of two concentric cylinder instruments in series, with which he studied many rheologieally anomalous materials. His work as an industrial chemist led him to take as wide an interest in suspensions as in sol-gel systems.

Pryce-Jones was one of the first to observe the phenomenon now generally named after Weissenberg (when a material climbs up a vertical rotating rod), which he characteristically referred to as the 
"Mae West Effect". As a result of his work on the thixotropy of honeys from certain floral sources, he became a leading authority on honey in general, and he wrote with considerable insight and knowledge about honey and about bee-keeping.

$\mathrm{He}$ was a fascinating lecturer and speaker, and both in Great Britain and abroad he had given lectures to various societies on his different specialisms. He had not only a great facility for explaining intricate problems to specialists, but also the ability of giving a simple, and yet scientifically accurate, picture to the layman. He was an omnivorous reader and bibliophile, and he could always be relied upon to make an illuminating contribution to any discussion.
His passing is a great loss to science, for he did much to stimulate scientific interests, particularly in the East Riding of Yorkshire. $\mathrm{He}$ was a former chairman of the Hull Branch of the Oil and Colour Chemists' Association and a past president of the Hull Chemical and Engineering Society.

$\mathrm{He}$ will be sadly missed at the meetings of scientific bodies and by his innumerable friends and associates in every walk of life: he was perhaps the perfect mixer.

$\mathrm{He}$ married, in 1921, Miss Helen Bune, who survives him. Their only son was lost in a tragic accident some years ago.

\section{Paut G. 'Espinasse}

BRYNMOR JONES

\section{NEWS and VIEWS}

Geological Survey of New Zealand :

Dr. L. I. Grange

Dr. L. I. Grange has retired from the post of director of the Geological Survey of New Zealand. Dr. Grange was born at Castlecliff, Wanganui, and in 1913 he won from Waihi School of Mines a Mines Department scholarship to attend the University of Otago. After war service in France during the First World War and further study at the University, he joined the N.Z. Geological Survey. Dr. Grange's professional career can be divided into three main phases : his work as a volcanologist in the Central North Island, his career as a pedologist culminating in his directorship of the Soil Bureau, and his return to the Geological Survey as director. For the Central North Island his bulletins on the geology of the Tongaporutu-Ohura and Rotorua-Taupo districts still remain authoritative publications. The lastnamed bulletin is a particularly important contribution to the world's knowledge of thermal activity. As a result of his work on soils, Dr. Grange became leader of a soil survey section of the Geological Survey, and in 1935 he was appointed director of a newly-formed Soil Survey Division. In 1940 he initiated a 4 miles/in. survey of the North Island, and followed this up by applying the results of the survey to practical problems. By 1946 physicists and biologists had been added to the soil team, and the Division was renamed the Soil Bureau. Later he extended his work beyond New Zealand to tropical soils in the Pacific Islands, where soil use in relation to population and food supplies is a problem. In 1952 Dr. Grange returned to the Geological Survey as director. During his term of office he has renewed his early interest in volcanology, and has compiled a departmental bulletin on "Geothermal Steam for Power in New Zealand", which gives a full picture of the work so far carried out in Wairakei. He recognized the probable impact on New Zealand of the important discoveries of radioactive minerals in Australia and after a visit to that country prepared and published a booklet, "Prospecting for Radioactive Minerals in New Zealand". In geology, soil surveys and soil conservation, Dr. Grange has made a notable contribution to New Zealand, and to the welfare of its people.

Mr. R. W. Willett

Mr. R. W. Wir.teTt has been appointed director of the New Zealand Geological Survey in succession to Dr. L. I. Grange. Mr. Willett was born in Dunedin in 1912. He was educated at Otago Boys' High School, the University of Otago and the Victoria University College. He joined the Geological Survey in 1936; he served as district geologist at Invercargill during 1942-48, and geologist-in-charge of the Coal Survey Section at Wellington during 1948-51. During 1951-54 he was seconded to the British Commonwealth Scientific Office (London) as liaison officer, and was the first to hold this office. Since returning to New Zealand he has been administrative assistant to Dr. Grange. Mr. Willett has published many scientific papers both in New Zealand and overseas. While in the United Kingdom he prepared a series of papers on the mineral resources of the British Commonwealth, and in 1954 was awarded the Silver Medal of the Royal Society of Arts for his paper on mineral resources of the British Common. wealth. His work in New Zealand has taken him into much of the mountain country of the South Island. $\mathrm{He}$ is at present foundation president of the Geological Society of New Zealand.

\section{Zoology at Calcutta :}

Prof. J. L. Bhaduri

THE sudden death of Prof. H. K. Mookerjee in August 1955 left vacant a key post in zoological education in India. This has now been filled by the appointment to the Sir Nil Ratan Sircar professorship and head of the Department of Zoology in the University of Calcutta of Dr. J. L. Bhaduri, a former student of the University. There he graduated B.Sc. with first-class honours in zoology in 1924, and M.Sc. two years later. After two further years, as teaching assistant, in the Zoology Department, he joined the Zoological Survey of India in 1929, and gained valuable field experience, under the guidance of Dr. Baini Prashad and the late Dr. S. L. Hora, in faunistic surveys in the Andamans and in studies of the frogs and toads of the Khashi Hills in Assam. In 1933 he was recalled to his old University as assistant lecturer, and there with increasing responsibility he has combined his recognized skill in teaching with enthusiasm for research. Dr. Bhaduri's main investigations have been concerned with Amphibia Salientia, their systematics, structure and ecology. He studied for two years in the Zoology Department of the University of Edinburgh, and the thesis on "The Urinogenital System of Salientia", for which he obtained the degree of D.Sc. in that University in 1947, contained, among other matters, a revealing correlation between structural modifications in the genital system and 